\title{
Diagnostic ultrasonography of the shoulder in dogs - scan techniques and common findings
}

\section{Ultrassonografia diagnóstica do ombro de cães - técnicas e principais achados}

\author{
Maria Lígia de Arruda Mistieri ${ }^{1 *}$; João Paulo Exaltação Pascon ${ }^{1}$; \\ Claudia Acosta Duarte ${ }^{1}$
}

\begin{abstract}
Determining the origin of lameness and pain in dog shoulder structures is considered a diagnostic challenge. Ultrasonography is an important diagnostic tool, capable of dynamically providing detailed information on muscle-tendon structures at a low cost. Its diagnostic accuracy for shoulder injuries is comparable to that of magnetic resonance imaging (MRI); however, the technique is still underestimated and underused in orthopedic examinations of small animals in Brazil. This study aimed to compile the literature data and explore the findings of ultrasound examinations for the diagnosis of abnormalities in the shoulder joint region of dogs. Scanning maneuvers of the tendons of the biceps brachii, supraspinatus, infraspinatus, teres minor, humeral head, and brachial plexus muscles were reviewed. The normal ultrasonographic patterns and findings that characterize different illnesses in this region were described. Key words: Diagnostic imaging, orthopedics, canine, tendon
\end{abstract}

\section{Resumo}

A determinação da origem de claudicação e dor das estruturas do ombro de cães é considerada desafio diagnóstico. A ultrassonografia é importante ferramenta diagnóstica capaz de fornecer informações detalhadas de estruturas músculo-tedíneas, de forma dinâmica e a baixo custo. Sua acurácia diagnóstica para lesões do ombro é comparável à da ressonância magnética, no entanto, nota-se que a técnica ainda é subestimada e subutilizada na rotina ortopédica de pequenos animais no Brasil. O presente trabalho tem o intuito de compilar dados da literatura e explorar o exame ultrassonográfico para o diagnóstico de anormalidades na região da articulação do ombro em cães. Foram revisadas as manobras de varredura dos tendões dos músculos bíceps braquial, supraespinhoso, infraespinhoso, redondo menor, cabeça umeral e plexo braquial. Foram descritos os padrões ultrassonográficos normais e os achados que caracterizam diferentes enfermidades dessa região.

Palavras-chave: Diagnóstico por imagem, ortopedia, canino, tendão

${ }^{1}$ Profs. Adjuntos, Pesquisadores, Universidade Federal do Pampa, UNIPAMPA, Uruguaiana, RS. Brasil. E-mail: mariamistieri@, unipampa.edu.br; joaopascon@unipampa.edu.br; claudiaduarte@unipampa.edu.br

* Author for correspondence 


\section{Introduction}

Forelimb lameness in dogs is considered a diagnostic challenge for clinicians. When pain is present in the shoulder region, particularly due to numerous soft tissue structures that may be affected and the limitations of radiographic examinations, the diagnosis tends to be compromised when other imaging techniques are not applied (MISTIERI et al., 2009; SILVA et al., 2013). In this context, diagnostic ultrasonography has been widely used in human orthopedic examinations since the 1970s (TEEFEY et al., 2000). Its application in small animal orthopedics has been widespread since the 1990s and includes descriptions of the anatomical and pathological ultrasound aspects of joints and long bones of dogs (KRAMER; GERWING, 1996, 2001; LAMB; WONG, 2005; RISSELADA et al., 2007; WALL et al., 2015). Although the technique allows accurate assessment of tendons, muscles, ligaments, articular surfaces, and even bone healing (KRAMER; GERWING, 1996; RISSELADA et al., 2007; COOK; COOK, 2009), its use is still restricted to a few centers in Brazil.

This review aims to compile the main techniques of ultrasound scanning related to the dog shoulder region structures, highlighting the most common findings and diagnoses.

\section{Anatomical review and clinical relevance}

The shoulder joint is classified as a simple synovial joint and is formed by the shallow glenoid cavity and broad humeral head. Although the joint congruence is not excellent, the joint allows the forelimb to perform curves in space, permitting movements in three different planes: extension flexion, adduction - abduction, and limited rotation, which enable locomotion (ROOS et al., 1993; COOK et al., 2005).

To ensure its stability and range of motion, the combined action of the joint capsule, lateral and medial glenohumeral ligaments (considered active stabilizers), and muscle groups (considered passive stabilizers) adjacent to the joint is necessary (ROOS et al., 1993).

In dogs, the muscles that contribute to shoulder stability include the supraspinatus and infraspinatus, which are found in the supraspinous (cranial) and infraspinous fossa (caudal) of the scapula, respectively, and enter the cranial and lateral aspect of the greater tubercle of the humerus; the subscapularis muscle, which is located in the subscapular fossa, distal to the serratus face and inserted in the lesser tubercle; and the biceps brachii muscle, which is craniomedial, originates in the scapular tuberosity, and crosses the intertubercular fossa under the intertubercular ligament. The tendons of the muscles described above are in close contact with the joint capsule. In addition to these structures, the deltoid, coracobrachialis, and teres major and minor muscles provide additional support to the joint, although they are not in direct contact with the capsule (CLAIR, 1986; BUTTERWORTH; COOK, 2006; SILVA et al., 2013).

Abnormalities of the bone structures and active and passive stabilizers of the shoulder joint result in manifestations of pain and lameness (SILVA et al., 2013; WASCHBURGER et al., 2014). Bone alterations, such as fractures and dislocations, are easily identified on radiographic evaluation. Alterations of the soft tissues involved in stabilizing the joint, such as tendonitis and muscle contractures, among others, are rarely identified in radiographic studies and require additional imaging techniques to obtain a diagnosis (KRAMER; GERWING, 2001; MISTIERI, 2008; MISTIERI et al., 2012; SILVA et al., 2013).

Among the most common orthopedic disorders of the shoulder region are articulation instability, which is essentially a clinical and arthroscopic diagnosis (MURPHY et al., 2008; WASCHBURGER et al., 2014), osteochondrosis and osteochondritis dissecans, bicipital tenosynovitis, calcific supraspinatus tendinitis, 
and fibrous contracture of the infraspinous, which requires other imaging methods, such as ultrasound and magnetic resonance imaging (MRI), for a diagnostic conclusion (BUTTERWORTH; COOK, 2006; SILVA et al., 2013).

\section{Ultrasonography in small animal orthopedics}

Ultrasonography has been previously described as an insensitive method in orthopedic evaluations (RIVERS et al., 1992). However, with the advent of higher resolution transducers, the method provides valuable information for the investigation of several soft tissue disorders and bone healing assessments. It has a wide range of applications in musculoskeletal evaluations, such as those of the shoulder, elbow, wrist, hip, knee, and tarsus, and several tendons and muscles have been examined using this technique. Its diagnostic sensitivity is comparable to that of MRI and arthroscopy, depending on the analyzed region (KRAMER et al., 1997, 1999; LONG, NYLAND, 1999; RICHARDS et al., 2001; LAMB; WONG, 2005; ROCHA; TORRES, 2007; COOK; COOK, 2009).

The advantages of ultrasonography implementation include speed, non-invasiveness, dynamic evaluation at different planes and positions of the studied articulation, and low cost, as long as the necessary equipment is available (DINNES et al., 2003; PAPATHEODOROU et al., 2006). However, the ultrasonography technique and its observations depend on the correct positioning of the patient, scanning protocol for each of the anatomical structures, dynamic observation of the images, observer experience, and existence of the appropriate transducer of the structure to be evaluated, which could limit the application of this technique (PAPATHEODOROU et al., 2006; OLIVEIRA et al., 2009). Another limitation is the need for sedation or anesthesia, depending on the structure and position of the articulation/limb to be examined (KRAMER et al., 1997).
For muscles, tendons, and ligaments, the ultrasound differentiation of alterations such as partial or complete ruptures, the formation of fibrous tissue, and the presence of abscess, hematoma, metaplasia, cancer, inflammation, and calcification is possible, and it is also useful in distinguishing active inflammation and asymptomatic calcification (GERWING; KRAMER, 1994; KRAMER et al., 1997; LAITINEN; FLO, 2000; KRAMER; GERWING, 2001; DINNES et al., 2003; BEGGS, 2004; OLIVEIRA et al., 2009; MISTIERI et al., 2012).

As in any similar evaluation, shaving the area is essential, as is the use of gel and the lateral decubitus position with the limb to be evaluated facing upward (KRAMER et al., 2004). The details for the procedures for the tendons and muscles most often evaluated in the shoulder region of dogs are compiled below, with the aim of highlighting the most commonly used maneuvers and visualized alterations.

\section{Biceps brachii muscle and tendon}

The standardization of the ultrasound examination of dog shoulders was described by Gerwing and Kramer (1994), who had previously advocated the need for sedation or anesthesia of the patient, especially for the evaluation of the tendon of the biceps brachii muscle. The exam is dynamic and should be performed with a 7.5 to $12 \mathrm{MHz}$ linear transducer (KRAMER et al., 1997, KRAMER; GERWING, 2001; MISTIERI et al., 2012).

The ultrasound assessment of this tendon is the most frequent procedure in the orthopedic evaluation of small animals and is mainly related to the diagnosis of inflammatory processes and ruptures (KRAMER; GERWING, 2001). Bicipital tenosynovitis is an important cause of forelimb lameness, especially in large dogs, and alterations in this tendon have often been observed in ultrasound evaluations (CANAPP JUNIOR, 2007; ISOLA et al, 2011; WASCHBURGER et al., 2014). 
For the correct positioning, maximum abduction and external rotation of the joint should be possible (Figure 1) because the structure is located medial to the joint, which makes the exam uncomfortable for the animal and justifies the need for anesthesia
(KRAMER; GERWING, 2001). These same authors report that the experience of the ultrasound technician and the standardization of positioning and scanning techniques are vital for the success of diagnosing alterations.

Figure 1. Photograph of the proper positioning of the tendon of the biceps brachii muscle in a dog for ultrasound examination. Note that abduction and the maximum external rotation are applied, which require sedation of the patient.

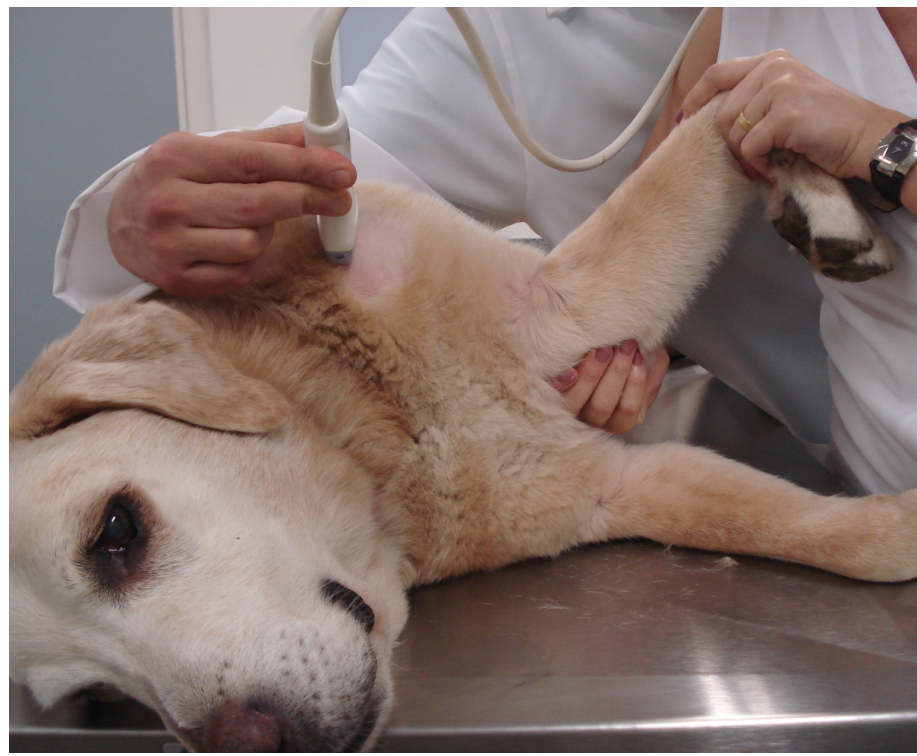

The assessment begins with longitudinal and transverse views of the muscle throughout its length (KRAMER; GERWING, 2001). It is noted that the muscle is more hypoechoic and has a more central hyperechoic strip that divides it into two bundles with a herringbone pattern. Then, the proximal musculotendinous transition is observed, the muscle bundle becomes thinner, and as the transducer moves in the proximal direction, the hyperechoic tendon can be observed (Figure 2). The examination of the tendon sheath, the tendon itself, and the intertubercular groove is preferably performed in the transverse plane. The ovalshaped tendon is more hyperechoic and is ventrally bound by the hyperechoic intertubercular groove, indicated by acoustic shadowing, and, throughout its circumference, by the sheath, which is also more hyperechoic. A narrow, hypo- or anechoic halo is observed between the tendon and its sheath due to the presence of the synovium (FIGURE 2) (KRAMER et al., 1997; KRAMER; GERWING, 2001).

Alterations such as tenosynovitis of different severities (Figure 3), exostoses in the intertubercular groove, partial or complete rupture, fracture of the supraglenoid tubercle, hematoma, loose cartilage fragments in the tendon sheath, or tumors can be diagnosed (KRAMER et al., 2004; CANAPP JUNIOR, 2007). Other imaging methods, such as arthroscopy and MRI with intra-articular contrast injection, can also diagnose inflammatory injuries and ruptures in this tendon but are much more invasive and of limited availability (MURPHY et al., 2008). In a recent report, ultrasonography proved as sensitive as MRI in the diagnosis of 
injuries in the bicipital tendon in humans, and

dynamic evaluation of the tendon (BATTAGLIA ultrasonography had the advantage of allowing the et al., 2015).

Figure 2. Ultrasound image of the transverse plane of the normal tendon of the biceps brachii muscle in a dog, obtained with a $12 \mathrm{MHz}$ linear transducer. Note the intertubercular groove represented by a hyperechoic line with acoustic shadowing (solid white arrow) that underlies the tendon; the tendon of the biceps brachii muscle (black solid arrow) is hyperechoic and shows normal echotexture; it is bound by a thin synovial sheath (dashed arrow: note the presence of the anechoic synovium surrounding the tendon).

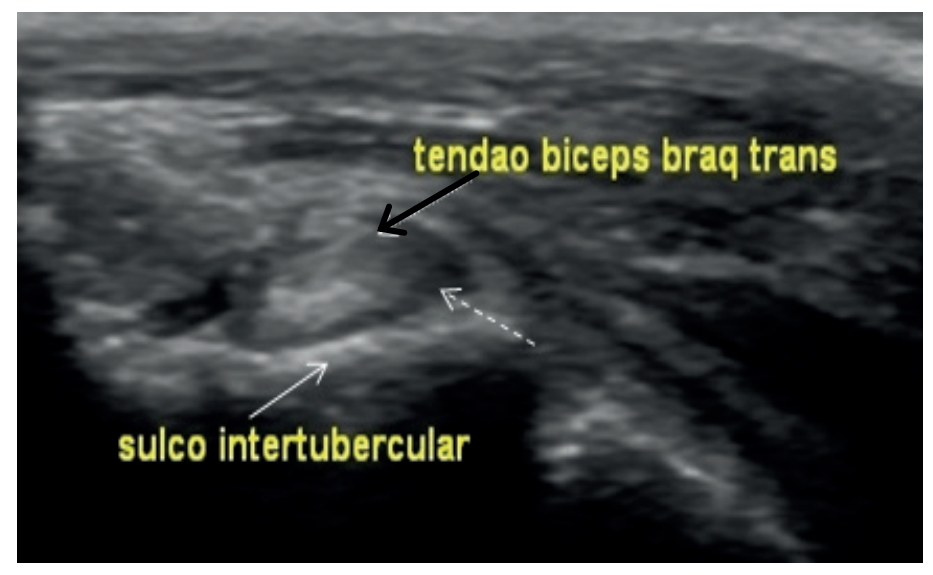

Figure 3. Ultrasound image in the transverse plane of the tendon of the biceps brachii muscle of a dog with tenosynovitis, which was obtained with a $14 \mathrm{MHz}$ linear transducer. Note the moderate distension of the synovial sheath (solid arrow) by synovial accumulation (anechoic halo delimited by a line) due to inflammation. Heterogeneity of the tendon parenchyma can also be observed (dashed arrow).

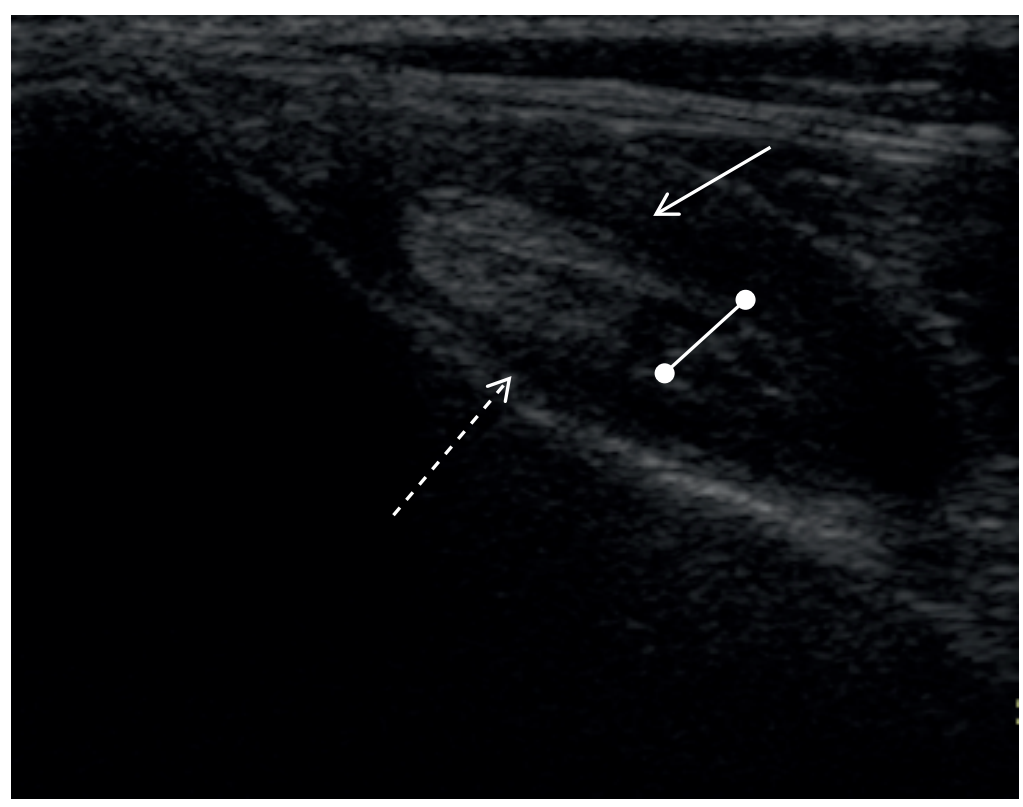

Ultrasonography has also been applied in dogs, permitting less invasive and faster guided tenotomy procedures of the biceps brachii in transcutaneous sectioning (ESTERLINE et al., 
2005; PEPPLER et al., 2009).

\section{Supraspinatus tendon and muscle}

An ultrasound examination of this muscle is commonly indicated after radiographic findings of calcified structures in the region of its insertion into the greater tubercle of the humerus (MISTIERI, 2008; MISTIERI et al., 2012).

For its assessment, the shoulder should be kept in an anatomical position, with an approximately $135^{\circ}$ flexion, and slightly rotated externally (LAFUENTE et al., 2009; MISTIERI, 2008). Although it does not cause discomfort, anesthesia is performed because the bicipital tendon is simultaneously evaluated in the same procedure, as retrospective studies have shown the relationship between the presence of large calcifications on the supraspinous tendon and bicipital tenosynovitis (MISTIERI, 2008; MURPHY et al., 2008).

The examination begins with the identification of the supraspinatus muscle, which is more hypoechoic, in the supraspinous fossa (Figure 4). The spine of the scapula is used as an anatomical reference and is observed as a hyperechoic structure with acoustic shadowing (Figure 4). Then, the 7.5 to $12 \mathrm{MHz}$ linear transducer is transversely positioned, and the scanning continues in the distal direction until the greater tubercle of the humerus is identified. At this stage, the transducer is rotated clockwise for observation, in the longitudinal plane, of the musculotendinous transition and the tendon itself. The transverse plane is obtained by anti-clockwise rotation of the transducer to the position orthogonal to the previously described position (KRAMER et al., 1997; MISTIERI et al., 2012).

Figure 4. Ultrasound image in the transverse plane of the normal supra and infraspinatus muscles of a dog, obtained with a $12 \mathrm{MHz}$ linear transducer. Note the scapular spine, which is the anatomical reference of intense echogenicity and acoustic shadowing (arrows) between the muscles. Note the pattern and texture of the normal muscles.

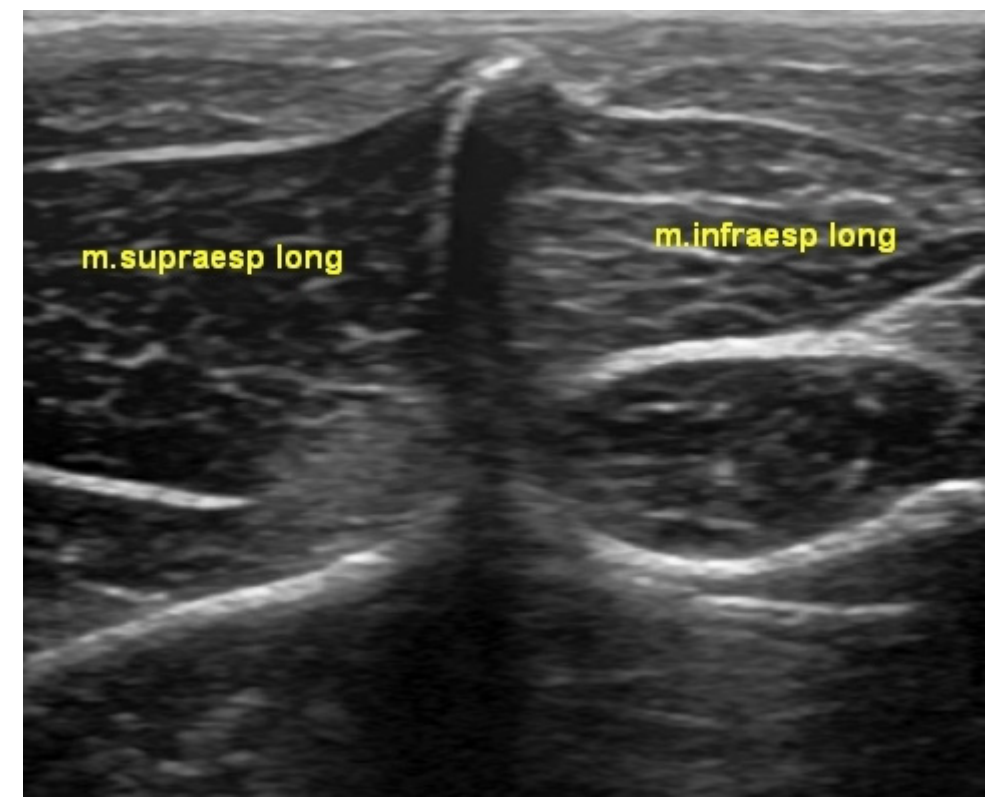

The most frequent alteration of the tendon of the supraspinatus muscle is tendinopathy with or without mineralization. This condition is characterized by different ultrasound patterns that include an increase of the total tendon area and echogenicity alterations of the tendon parenchyma 
with or without mineral deposits (LAFUENTE et al., 2009; MISTIERI, 2008; MISTIERI et al., 2012).

Calcifications are characterized by the presence of hyperechoic structures in the tendon parenchyma with irregular boundaries that may form an acoustic shadow (Figure 5); in most cases, the calcifications do not exhibit a surrounding inflammatory reaction (GERWING; KRAMER, 1994; MISTIERI et al., 2009, 2012). The additional visualization of an anechoic halo surrounding the calcification has been referred to as a possible inflammatory process and correlated with the manifestation of clinical signs (MISTIERI et al., 2012). However, tendinopathies of the supraspinatus are commonly asymptomatic and considered diagnostic findings; therefore, ultrasound or magnetic resonance evaluation in the search for evidence of the presence of inflammation is essential for the correlation between the clinical manifestations of the patient and such findings (MISTIERI, 2008; MURPHY et al., 2008).

Figure 5. Ultrasound image in the longitudinal plane of the supraspinatus muscle tendon of a dog with tendinosis, obtained with a $12 \mathrm{MHz}$ linear transducer. Note the tendon insertion in the greater tubercle of the humerus (Tub). The supraspinatus tendon, seen as the most hyperechoic structure (solid arrows), is delineated, and a hyperechoic structure is observed in its parenchyma (dashed arrow) with distal acoustic shadowing, which is characteristic of calcific tendinosis.

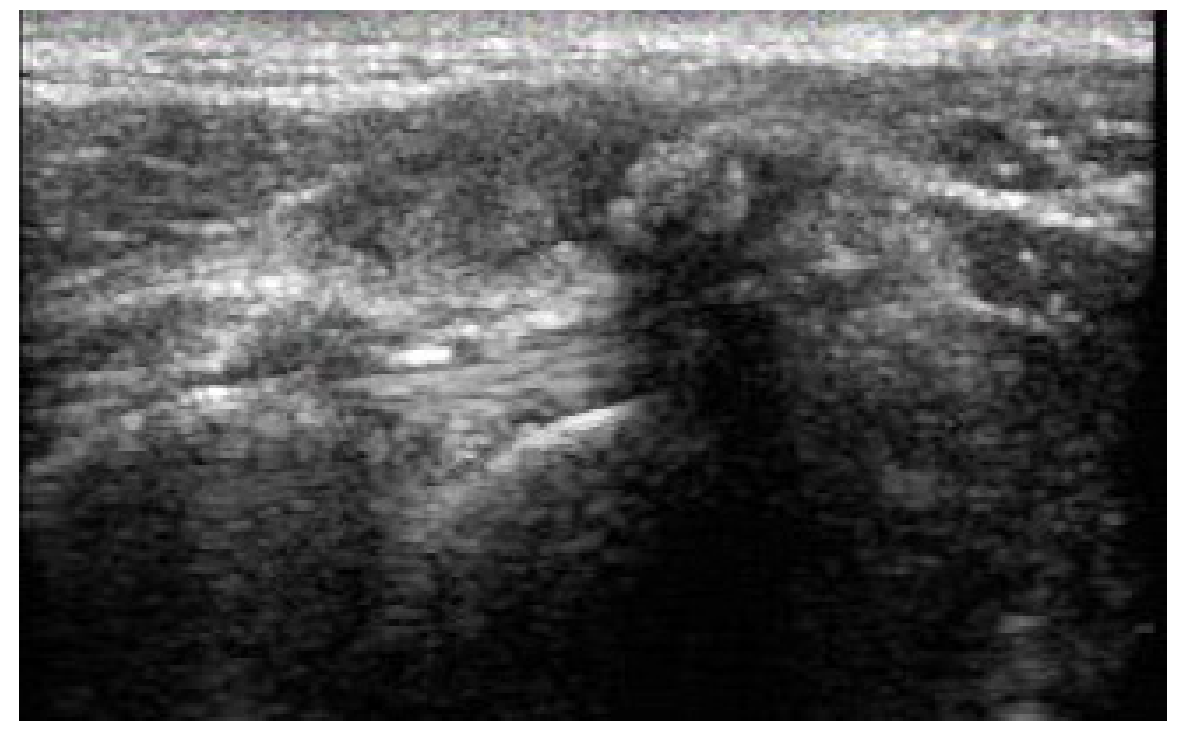

\section{Infraspinatus tendon and muscle}

This muscle is more commonly evaluated by ultrasonography in cases of clinical suspicion of contracture (SAMII; LONG, 2005; CARNEIRO et al., 2014). The positioning is similar to that described for the evaluation of the supraspinatus tendon and muscle. The infraspinatus muscle, located in the caudolateral aspect of the scapular spine (infraspinous fossa), is observed as a more hypoechoic and slightly heterogeneous structure. As the transducer is moved caudally, the tendon fibers are observed, and the tendon of the infraspinatus muscle, which is more hyperechoic and thinner, is visible until its insertion into the lateral aspect of the greater tubercle of the humerus (SAMII; LONG, 2005). Although uncommon, the main injury of this tendon is caused by contracture, and in this case, the tendon and muscle become more hyperechoic than normal (KRAMER et al., 1997; HARASEN, 2005; CARNEIRO et al., 2014). Reports show that MRI 
has also been used successfully in the diagnosis of contracture of the infraspinatus (ORELLANAJAMES et al., 2013). Calcifying tendinopathy of the infraspinatus muscle has also been described in dogs (PADILHA FILHO et al., 2012).

\section{Teres minor and tendon}

The ultrasound examination of this structure is indicated in suspected myopathy (BRUCE et al., 1997). The teres minor is observed at a deeper depth than the deltoid muscle, caudally to the infraspinatus muscle and proximally to the shoulder joint. To facilitate its visualization, abduction with lateral rotation of the distal humerus is conducted. As an anatomical reference, the subscapular artery can be observed in the deep layers. Its normal ultrasound aspect is hypoechoic with well-marked echotexture. Although uncommon, minor teres myopathy may be evaluated via this examination when there is an increase in muscular echogenicity. This assessment is very uncommon in orthopedic ultrasound procedures, and a few studies have been published regarding these structures and ultrasonography (BRUCE et al., 1997; SAMII; LONG, 2005).

\section{Glenohumeral joint}

For the assessment of the glenohumeral joint, a $12 \mathrm{MHz}$ linear transducer must be positioned caudolaterally to the joint, using the acromion as a reference. After proper positioning of the transducer, the shoulder should be abducted and rotated medially as much as possible (KRAMER et al., 1997; VANDEVELDE et al., 2006). In practice, this position has proven to be relatively uncomfortable, which indicates the use of general anesthesia in dogs.

The subchondral bone of the normal humeral head is observed as a convex hyperechoic line with strong distal acoustic shadowing, and the joint cartilage is observed as an anechoic layer of uniform thickness with a hyperechoic surface interface. Irregularities on the bone surface, inaccurate contours and/or thickening of the hyaline cartilage, and the presence of loose bodies in the joint without acoustic shadowing and joint distension can be observed in dogs with osteochondrosis/osteochondritis dissecans (OC/OCD) of the humeral head using this technique (VANDEVELDE et al., 2006).

The ultrasound evaluation of the shoulder joint was described by Kramer et al. (1997) as an auxiliary method for radiographic evaluation capable of providing additional information regarding the shape of the articular surface of the humerus and the increase and alteration in the synovial liquid and joint capsule. Subsequently, the accuracy of the ultrasound technique was compared to that of radiography, arthrography and arthroscopy, computed tomography, and MRI for the diagnosis of OC/OCDA. Ultrasonography has proven to be sensitive in identifying subchondral defects and cartilage flaps but less sensitive in the identification of cartilage thickening, articular distension, and the detection of loose joint fragments (VANDEVELDE et al., 2006; WALL et al., 2015).

The acoustic window for the assessment of the humeral joint surface is small and requires a well-trained examiner (VANDEVELDE et al., 2006). A recent study compared radiographic, ultrasonographic, and MRI evaluations in cases of OC/OCD and concluded that ultrasonography was less specific and accurate than the other techniques and extremely linked to the experience of the examiner. In this same study, the authors concluded that assessment by MRI was more reliable than that by ultrasound and radiography (WALL et al., 2015).

\section{Brachial plexus}

Although alterations of the brachial plexus are not classified as orthopedic, it is routinely assessed when performing ultrasonography of the shoulder region of dogs because alterations in its components can lead to lameness and should be included in the differential diagnosis GERMING; 
KRAMER, 1994; Several ultrasound windows have been described for the visualization of the brachial plexus (GUILHERME; BENIGNI, 2008). Among them, the positioning of the linear transducer, with a frequency of 8 to $12 \mathrm{MHz}$, in the armpit of the animal in the lateral decubitus position with craniocaudal alignment is routinely performed. In this position, the free limb can be extended and abducted approximately $30^{\circ}$, and there is no need for general anesthesia (ROSE et al., 2005; GUILHERME; BENIGNI, 2008).

In normal dogs, the axillary veins and arteries are easily recognizable and confirmed with Doppler color flow. Between both structures, spinal nerves that contribute to the formation of the plexus are identified as hypoechoic and are 2-3 mm thick in the transverse plane (Figure 6). The greater tubular structures, which may be rounded or oval and hypoechoic, hyperechoic, or heterogeneous, are characterized as masses in the plexus and must be investigated by cytology or a biopsy for a diagnostic conclusion (KRAMER et al., 2004; ROSE et al., 2005).

Figure 6. Ultrasound image of the deep axillary region of a dog in the transverse plane. Note the presence of blood vessels highlighted by the Doppler color (inside the square) and rounded and hypoechoic areas (arrows) that can be identified next to the vascularization, which correspond to the nerve components of the brachial plexus.

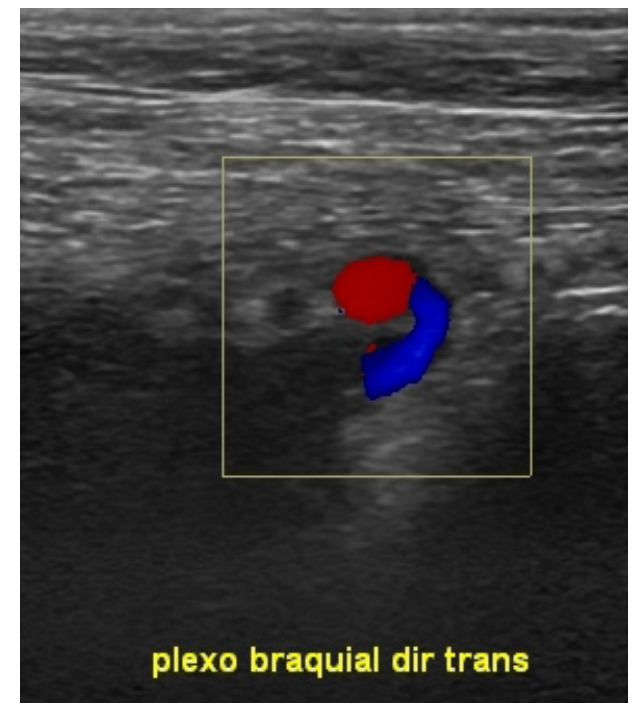

\section{Conclusion}

Ultrasonography can provide detailed information regarding several alterations of the canine shoulder region, especially in musculotendinous structures. The information obtained through this examination complements radiographic evaluations and allows the diagnostic investigation of inflammatory and calcifying processes, contractures, and cancer, when suspected.

\section{References}

BATTAGLIA, P. J.; WELK, A. B.; KETTNER, N. W. Ultrasound appearance and dynamic evaluation of variant long head of the biceps tendon anatomy with MRI correlation. Journal of Ultrasound, Pavia, v. 18, n. 2, p. 187-189, 2015.

BEGGS, I. Alternative imaging techniques. Magnetic Resonance Imaging Clinics of North America, Cambridge, v. 12, n. 1, p. 75-96, 2004.

BRUCE, W. J.; SPENCE, S.; MILLER, A. Teres minor myopathy as a cause of lameness in a dog. Journal of Small Animal Practice, Oxford, v. 38, n. 2, p. 74-77, 1997.

BUTTERWORTH, S.; COOK, J. L. The shoulder. In: HOULTON, J. E. F.; COOK, J. L.; INNES, J. F.; LANGLEY-HOBBS, S. J. Manual of canine and feline musculoskeletal disorders. BSAVA: Gloucester, 2006. p. 212-248.

CANAPP JUNIOR, S. O. Injuries in sporting and working dog. In: NAVC NORTH AMERICAN VETERINARY CONFERENCE, 2007, Orlando. Anais... Orlando: The North America Veterinary Comunity, 2007. p. 1314.

CARNEIRO, L. Z.; WASCHBURGER, D. J.; PASCON, J. P. E.; MISTIERI, M. L. A. Diagnóstico precoce e tratamento conservativo na contratura do músculo infraespinhoso - relato de caso. In: CONGRESSO BRASILEIRO DE CIRURGIA DO CBCAV, 11., 2014, Bento Gonçalves. Anais... Bento Gonçalves: Colégio Brasileiro de Cirurgia Veterinária, 2014. p. 207.

CLAIR, L. E. St. Músculos. In: GETTY, R. Anatomia dos animais domésticos. 5. ed. Rio de Janeiro: Guanabara Koogan, 1986. v. 2, cap. 50, p. 1416-1440.

COOK, C.; COOK, J. L. Diagnostic imaging of canine elbow dysplasia: a review. Veterinary Surgery, Philadelphia, v. 38, n. 2, p. 144-153, 2009. 
COOK, J. L.; RENFRO, D. C.; TOMLINSON, J. L.; SORENSEN J. E. Measurement of angles of abduction for diagnosis of shoulder instability in dogs using goniometry and digital image analysis. Veterinary Surgery, Philadelphia, v. 34, n. 5, p. 463-468, 2005.

DINNES, J.; LOVEMAN, E.; MCINTYRE, L.; WAUGH, N. The effectiveness of diagnostic tests for the assessment of shoulder pain due to soft tissue disorders: a systematic review. Health Technology Assessment, Winchester, v. 7, n. 29, p. 1-166, 2003.

ESTERLINE, M. L.; ARMBRUST, L.; ROUSH, J. K. A comparison of palpation guided and ultrasound guided percutaneous biceps brachii tenotomy in dogs. Veterinary and Comparative Orthopaedics and Traumatology, Stuttgart, v. 18, n. 3, p. 135-139, 2005.

GERWING, M.; KRAMER, M. Die sonographie der schlutergelenkes und seiner umgebenden weichteile beim hund. Kleintierpraxis, Hannover, v. 39, n. 3, p. 141156, 1994.

GUILHERME, S.; BENIGNI, L. Ultrasonographic anatomy of the brachial plexus and major nerves of the canine toracic limb. Veterinary Radiology \& Ultrasound, Raleigh, v. 49, n. 6, p. 577-583, 2008.

HARASEN, G. Infraspinatus muscle contracture. Canadian Veterinary Journal, Ottawa, v. 46, n. 8, p. 751752, 2005.

ISOLA, J. G. M. P.; MORAES, P. C.; SELMI, A. L. Importância da reabilitação após procedimento cirúrgico para o tratamento de tenossinovite bicipital - relato de caso. Revista Científica Eletrônica de Medicina Veterinária, Garça, ano IX, v. 16, n. 1, p. 1-9, 2011.

KRAMER, M.; GERWING, M. Die bedeutung der sonographie in der orthopädie beim hund. Berliner und Münchener Tierärztliche Wochenschrift, Hannover, v. 109, n. 4, p. 130-135, 1996.

Ultrasonography for the diagnosis of diseases of the tendon and tendon sheath of the biceps brachii muscle. Veterinary Surgery, Davis, v. 30, n. 1, p. 64-71, 2001.

KRAMER, M.; GERWING, M.; HACH, V.; SCHIMKE, E. Sonography of the musculoskeletal system in dogs and cats. Veterinary Radiology \& Ultrasound, Raleigh, v. 38, n. 2, p. 139-149, 1997.

KRAMER, M.; GERWING, M.; MICHELE, U. What does ultrasound tell us about orthopaedic problems. In: EUROPEAN SOCIETY OF VETERINARY ORTHOPAEDICS AND TRAUMATOLOGY CONGRESS, 12., 2004, Munich. Proceedings... Munich: Ludwig-Maximilians University, 2004. v. 1, p.51-53.
KRAMER, M.; STENGEL, H.; GERWING, M.; SCHIMKE, E.; SHEPPARD, C. Sonography of the canine stifle. Veterinary Radiology \& Ultrasound, Raleigh, v. 40, n. 3, p. 282-293, 1999.

LAFUENTE, M. P.; MARTINEZ, S. A.; GAVIN P. R.; LAHMERS, K. K; GAY, J. M. Surgical treatment of mineralized and nonmineralized supraspinatus tendinopathy in twenty-four dogs. Veterinary Surgery, Davis, v. 38, n. 3, p. 380-387, 2009.

LAITINEN, O. M.; FLO, G. L. Mineralization of the supraspinatus tendon in dogs: a long-term follow-up. Journal of the American Animal Hospital Association, Lakewood, v. 36, n. 3, p. 262-267, 2000.

LAMB, C. R.; WONG, K. Ultrasonographic anatomy of the canine elbow. Veterinary Radiology \& Ultrasound, Raleigh, v. 46, n. 4, p. 319-325, 2005.

LONG, C.; NYLAND, T. Ultrasonographic evaluation of the canine shoulder. Veterinary Radiology \& Ultrasound, Raleigh, v. 40, n. 4, p. 372-379, 1999.

MISTIERI, M. L. Tendinose calcificante do músculo supraespinhoso em cães. 2008. Tese (Doutorado em Cirurgia Veterinária) - Universidade Estadual Paulista, Jaboticabal.

MISTIERI, M. L. A.; KRAMER, M.; CANOLA, J. C.; PADILHA FILHO, J. G. Tendinose do supraespinhoso em cães. Semina: Ciências Agrárias, Londrina, v. 30, n. 3, p. 693-700, 2009.

MISTIERI, M. L.; WIGGER, A.; CANOLA, J. C.; FILHO, J. G.; KRAMER, M. Ultrasonographic evaluation of canine supraspinatus calcifying tendinosis. Journal of American Animal Hospital Association, Lakewood, v. 48, n. 6, p. 405-410, 2012.

MURPHY, S. E.; BALLEGEER, E. A.; FORREST, L. J.; SHAEFER, S. L. Magnetic resonance imaging findings in dogs with confirmed shoulder pathology. Veterinary Surgery, Philadelphia, v. 37, n. 7, p. 631-638, 2008.

OLIVEIRA, R. O.; MAMPRIM, M. J.; RAHAL, S. C.; BICUDO, A. L. C. Radiografia e ultrassonografia no diagnóstico de ruptura de ligamento cruzado cranial em cães. Pesquisa Veterinária Brasileira, Seropédica, v. 29, n. 8, p. 661-665, 2009.

ORELLANA-JAMES, N. G.; GINJA, M. M.; REGUEIRO, M.; OLIVEIRA, P.; GAMA, A.; RODRIGUEZ-ALTONAGA, J. A.; GONZALOORDEN, J. M. Sub-acute and chronic MRI findings in bilateral canine fibrotic contracture of the infraspinatus muscle. Journal of Small Animal Practice, West Sussex, v. 54 , n. 8 , p. $428-431,2013$. 
PADILHA FILHO, J. G.; SOUZA, S. F.; MISTIERI, M. L. A. Tendinopatia calcificante em um cão Cocker Spaniel. Jornal Brasileiro de Cirurgia Veterinária, Curitiba, v. 2, n. 2, p. 142-145, 2012.

PAPATHEODOROU, A.; ELLINAS, P.; TAKIS, F.; TSANIS, A.; MARIS, I.; BATAKIS, N. US of the shoulder: rotator cuff and non-rotator cuff disorders. RadioGraphics, Oak Brook, v. 26, n. 1, e23, 2006.

PEPPLER, C.; KRAMER M.; GERWING, M. Ultrasound guided percutaneous tenotomy of the bicpes tendon in five dogs with tendovaginitis - preliminary results. Tierärztliche Praxis, Stuttgart, v. 37, n. 3, p. 167172, 2009.

RICHARDS, P. J.; DHEER, A. K.; McCALL, I. M. Achilles tendon (TA) size and power Doppler ultrasound (PD) changes compared to MRI: a preliminary observational study. Clinical Radiology, London, v. 56, n. 10, p. 843-850, 2001.

RISSELADA, M.; VAN BREE, H.; KRAMER, M.; VERLEYEN P.; SAUNDERS, J. H. Ultrasonographic assessment of fracture healing after plate osteosynthesis. Veterinary Radiology and Ultrasound, Raleigh, v. 48, n. 4, p. 368-372, 2007.

RIVERS, B.; WALLACE, L.; JOHNSTON, J. R. Biceps tenosynovitis in the dog - radiographic and sonographic findings. Veterinary and Comparative Orthopaedics and Traumatology, Stuttgart, v. 5, n. 2, p. 51-57, 1992.

ROCHA, B. D.; TORRES, R. C. S. Ultrasonic and radiographic study of laxity in hip joints of young dogs. Arquivos Brasileiros de Medicina Veterinária e Zootecnia, Belo Horizonte, v. 57, n. 1, p. 90-96, 2007.

ROOS, H.; RAUSCHER, T.; BRUGGER, S. Die biologische wertigkeit der bewegungen im shultergelenk von katze und hund. Tierärztliche Praxis, Stuttgart, v. 21, n. 3, p. 323-327, 1993.
ROSE, S.; LONG, C.; KNIPE, M.; HORNHOF, B. Ultrasonographic evaluation of brachial plexus tumors in five dogs. Veterinary Radiology \& Ultrasound, Raleigh, v. 46, n. 6, p. 514-517, 2005.

SAMII, V. F.; LONG, C. D. Sistema musculoesquelético. In: NYLAND, T. G.; MATTOON, J. S. Ultra-som diagnóstico em pequenos animais. São Paulo: Editora Roca, 2005. cap. 14, p. 273-291.

SILVA, H. R.; UOSITE, R; CLEMENTS, D. N.; BERGKVIST, G. T.; SCHWARZ, T. Computed tomography and positive contrast computed tomographic arthrography of the canine shoulder: normal anatomy and effects of limb position on visibility of soft tissue structures. Veterinary Radiology \& Ultrasound, Raleigh, v. 54, n. 5, p. 470-477, 2013.

TEEFEY, S. A.; HASAN, S. A.; MIDDLETON, W. D.; PATEL, M.; WRIGHT, R. W.; YAMAGUCHI, K. Ultrasonography of the rotator cuff: a comparison of ultrasonographic and arthroscopic findings in one hundred consecutives cases. Journal of Bone and Joint Surgery, Boston, v. 82a, n. 4, p. 298-504, 2000.

VANDEVELDE, B.; VAN RYSSEN, B.; SAUNDERS, J. H.; KRAMER, M.; VAN BREE, H. Comparison of the ultrasonographic appearance of osteochondrosis lesions in the canine shoulder with radiographiy, arthrography, and arthroscopy. Veterinary Radiology \& Ultrasound, Raleigh, v. 47, n. 2, p. 174-184, 2006.

WALL, C. R.; COOK, C. R.; COOK, J. L. Diagnostic sensitivity of radiography, ultrasonography, and magnetic resonance imaging for detecting shoulder osteochondrosis/osteochondritis dissecans in dogs. Veterinary Radiology \& Ultrasound, Raleigh, v. 53, n. 1, p. 3-11, 2015.

WASCHBURGER, D.; SARTURI, V. Z.; MISTIERI, M. L. A.; DUARTE, C.A. Principais afecções do ombro de cães adultos. Revista Científica de Medicina Veterinária, Garça, ano 12, v. 1, n. 22, p. 1-18, 2014. 
